\title{
Increasing Work Engagement with Employees' Perceptions of Psychological Climate-Based Organizational Changes
}

\author{
Rini Rahmawati ${ }^{1}$, Ali Wardhana ${ }^{2}$, Asrid Juniar ${ }^{3, *}$ \\ ${ }^{1}$ Faculty of Economics and Business, Lambung Mangkurat University, Banjarmasin, Indonesia \\ ${ }^{2}$ Faculty of Economics and Business, Lambung Mangkurat University, Banjarmasin, Indonesia \\ ${ }^{3}$ Faculty of Economics and Business, Lambung Mangkurat University, Banjarmasin, Indonesia \\ ${ }^{*}$ Corresponding author.Email: asridjuniar@ulm.ac.id
}

\begin{abstract}
This study aims to analyze the effect of employee perceptions of organizational change on the psychological climate and work engagement, as well as to analyze the reciprocal effect of psychological climate and work involvement on employees of regionally owned enterprises in Banjarmasin City. Employee perceptions of organizational change are measured by indicators of employee development skills, employee engagement change, employee trust, fear of consequence change, performance enhancement. Psychological climate is measured by indicators of supportive management, role clarity, freedom express self, confession organization, contribution which is given employees in line with target company, jobs that challenge. Work involvement is measured by indicators with identification psychologically on work and work result influence pride. This study uses the SEMPLS analysis technique with the number of respondents as many as 65 employees. Based on the results of data analysis shows that employees' perceptions of organizational change have a significant effect on the psychological climate but have no significant effect on work engagement. The results showed that the psychological climate and work involvement had a reciprocal relationship. The results also show that the psychological climate is important for regionally selected business entities in Banjarmasin City to adapt to changes after restructuring the company's management.
\end{abstract}

Keywords: Perception of organizational change, Psychological climate, Work engagement.

\section{INTRODUCTION}

Every organization will face changes in the organizational climate that will have an impact on work engagement for employees in an organization. The existence of a new paradigm that occurs in the management of an organization will also have an impact on the psychological condition of each employee. According to [1] there is a form of appreciation for the impact of global climate change, both psychologically, socially, technologically and ecologically. This means that organizational changes as a result of global changes will also have an impact on the psychological climate of the organization.

[2] stated that the psychological climate is the organizational environment that has been perceived and interpreted by employees. Psychological climate is also a perception of the characteristics of situations that have psychological meaning or meaning that can affect the behavior, attitudes of individuals from members of an organization [3]. There is a favorable climate if it is able to produce a solution, a loyal attitude, good cooperation, increased motivation and job satisfaction and a willingness for individuals to strive optimally and with quality in their work. On the other hand, an unfavorable climate will result in high work stress, time work is used to talk to each other, tend to change jobs, absenteeism due to illness, reduced communication with superiors and low job satisfaction or work involvement. Psychological climate can be defined as a condition attached to employees regarding procedures, methods, policies in an organization, which can be felt by employees 
through their behavior because they feel valued, expected and supported by the organization [4], [5].

Organizational change is a business that has risks, among others, will experience failure that arises from ideas or initiatives. Goals in generating opportunities and high process costs, which sometimes outweigh the benefits of organizational change [6].

According to [2] that psychological climate has a positive relationship with the performance shown through employees. In line with this, [7] stated that the psychological climate has a variety of relationships with organizational behavior, including employee work involvement. The results of the research by [7] show that the psychological climate has a variety of relationships with employee organizational behavior, including employee work involvement.

This study was conducted to see how the role of psychological climate as a mediation of work involvement and organizational change in employees of regionally owned enterprises in Banjarmasin City, South Kalimantan Province which has undergone restructuring. This change is in line with the reform and bureaucracy which is one of the government's efforts to achieve good governance and carry out reforms and fundamental changes to the system of governance, especially regarding institutional aspects. problem. These changes have both internal and external influences. Organizational changes also have an impact on other changes, such as employee attitudes and behavior. Internal influence is the influence on employees directly, especially in carrying out daily tasks, employee perceptions, psychological climate and work involvement. Based on the background and the results of previous studies, the novelty of this study is to see the reciprocal relationship between psychological climate and work engagement.

\subsection{Psychological Climate}

Psychological climate describes the climate in the company that causes employees to like their work wholeheartedly or it can cause psychological barriers to their work [8]. Psychological climate is an expression or expression of the overall mood that is manifested by the psychological nuances felt by employees [2]. Then [7] said that the psychological climate is the visualization of the individual to the structure and processes of an organization. Furthermore, the psychological climate will have an influence on the attitudes of employees related to work attitudes, psychological well-being, motivation to individuals related to employee cognitive assessments of their environment. Psychological climate is also a perception of the characteristics of situations that have psychological meaning or meaning that can affect the behavior, attitudes of individuals from members of an organization [3].

Several studies have been conducted related to the psychological climate, among others, by [9]-[11] who developed the dimensions of psychological climate stated that psychological climate reflects a multidimensional concept, where psychological climate is described as a construction that provides an individual psychological representation of processes, events and structures. According to [12] in his research stated that the psychological climate is a source of strength from business and core values that can unite all members in the organization so that they become one unit. only one member, then if employees feel happy, comfortable, happy then their creativity and abilities will be created effectively. Employees will perceive their organizational environment positively by involving them in their work with more effort and producing high work performance [13]. According to [14] that it is important for organizations to improve the climate of the work environment so that employees can enjoy their work and are experienced.

Based on the explanation of the research results that have been described, climate is a characteristic that distinguishes an organization from other organizations and affects the behavior of individuals in the organization. And psychological climate is the perception of the characteristics of work situations that have psychological meaning and can affect the behavior and attitudes of individual members of the organization. According to [2] there are 6 (six) dimensions, namely as follows: 1 . The existence of support from management (supportive management) is considered supportive and flexible 2. The existence of role clarity (role clarity) 3. Freedom of selfexpression (self-expression) 4. Organizational recognition (recoqnition) 5. Employee contributions are in line with company goals 6 . Challenging work.

\subsection{Work Engagement}

[8] states that work engagement is a personal involvement of organizational members in their work, then in this involvement a person will express himself and do his work physically, cognitively and emotionally. Then [15] stated that work engagement is a concept of employee motivation in using the resources they have for their work. Work engagement is an involvement in psychological conditions [16]. According to [8] in his research states that to see employee engagement means being physically 
involved, cognitively alert and having a sense of empathy with others in the workplace. Employees who have great opportunities in their work will take sides with the type of work and care about their work, so that it will encourage high work involvement among employees. This can be used to improve performance, foster positive attitudes and behavior from employees [17].

\subsection{Perception of Organizational Change}

Organizational change will be a burden on all parties in the organization, including employees. Furthermore, factually organizational change can be applied if the organization wants to achieve success. The strategy in this change must be developed from the psychological aspect of employees because if there is a failure it will be able to influence the idea to make further changes. job satisfaction, trust in the organization and motivation of employees [18].

Changes that occur in the organization will raise the perception of every employee who is directly involved in the impact of these changes. Perception is the process by which people receive, organize, and interpret information about their environment. Perception involves being aware of the world around us and processing information about that world. Social perception will help us form an opinion and judgment about other people. Social perception is interesting because there are so many managerial activities [19].

\subsection{Perception, Psychological Climate and Work Engagement}

Based on the theory and research results that have been carried out related to perceptions of organizational change with its environment (psychological climate) and the effect on work engagement, as done by [7], [9]-[11], [14], [16], [18], [19] then the hypothesis proposed in this study is as follows:

H1: employee perceptions of organizational change have a significant effect on the psychological climate

$\mathrm{H} 2$ : employee perceptions of organizational change have a significant effect on work engagement

H3: psychological climate has a significant effect on work engagement

H4: work engagement has a significant effect on psychological climate

\section{METHODOLOGY}

This research was conducted on employees in regionally owned enterprises in Banjarmasin City, South Kalimantan province, amounting to 65 respondent. The sampling technique is saturated sample where the entire population is sampled. Data was taken using a questionnaire. Data analysis technique using SEM-PLS.

The research variable consists of one exogenous variable, namely employee perceptions of organizational change as measured by indicators of employee development skills, employee engagement change, employee trust, fear of consequence change, performance enhancement. This study uses two endogenous variables, namely the psychological climate measured by supportive management, role clarity, freedom express self, confession organization, contribution which is given employees in line with target company, and jobs that challenge. The next variable is work engagement which is measured by identification psychologically on work and work result that influence pride. The overall research model is shown in Figure 1.

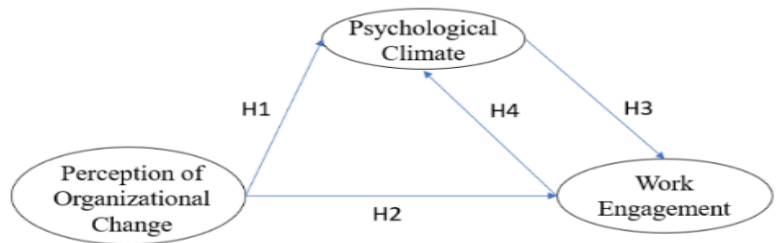

Figure 1. Research Model

\section{RESULTS AND DISCUSSION}

Based on the number of 65 respondents in this study, namely employees of regionally-owned enterprises in the municipality of Banjarmasin, 26 respondents (40\%) were female and $39(60 \%) .78 \%)$. The respondent's tenure is $6-10$ years $(25 \%)$. The research model after being entered into the SEM-PLS software is presented in Figure 2.

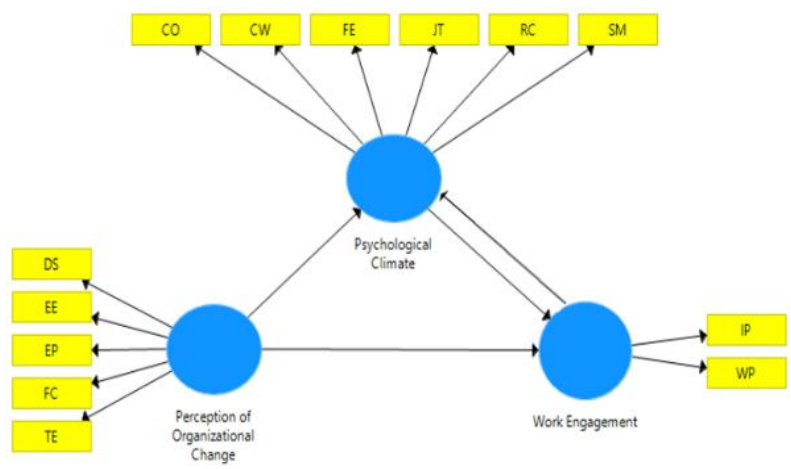

Figure 2. SEM-PLS Structural Model 
Based on the structural model that has been built, validity and reliability tests were carried out. Based on the results of the SEM-PLS output in the calculation results of the outer loading value of all indicators the value is greater than 0.5 so that all indicators can be used in the research model. The Average Variance Extracted (AVE) values are all variables, the value is greater than 0.5 so that it meets the requirements of convergent validity, meaning that this research model has good discriminant validity. The result of validity and reliability tests, as presented in Table 1, shows that the AVE value of psychological climate is 0.787 ; work involvement is 0.876; and employee perceptions of organizational change is 0.792 .

Table 1. Test Results of Structural Model Validity and Reliability

\begin{tabular}{|c|c|c|c|c|}
\hline Variable & Indicator & $\begin{array}{c}\text { Outer } \\
\text { loading }\end{array}$ & AVE & $\mathrm{CR}$ \\
\hline \multirow{5}{*}{$\begin{array}{l}\text { Perception of } \\
\text { Organizational } \\
\text { Change }\end{array}$} & $\begin{array}{l}\text { Development skill } \\
\text { employee }\end{array}$ & 0.761 & \multirow{5}{*}{0,792} & \multirow{5}{*}{0,815} \\
\hline & $\begin{array}{l}\text { Engagement } \\
\text { Employees } \\
\text { inchange }\end{array}$ & 0.718 & & \\
\hline & Trust employee & 0.724 & & \\
\hline & $\begin{array}{l}\text { Fear of } \\
\text { consequence } \\
\text { change }\end{array}$ & 0.707 & & \\
\hline & $\begin{array}{l}\text { Enhancement } \\
\text { Performance }\end{array}$ & 0,661 & & \\
\hline \multirow{6}{*}{$\begin{array}{l}\text { Psychological } \\
\text { Clomate }\end{array}$} & $\begin{array}{l}\text { Supportive } \\
\text { Management }\end{array}$ & 0.644 & \multirow{6}{*}{0,787} & \multirow{6}{*}{0,915} \\
\hline & Role Clarity & 0.619 & & \\
\hline & $\begin{array}{l}\text { Freedom express } \\
\text { self }\end{array}$ & 0.640 & & \\
\hline & $\begin{array}{l}\text { Confession } \\
\text { Organization }\end{array}$ & 0.589 & & \\
\hline & $\begin{array}{l}\text { Contribution which } \\
\text { is givenemployees } \\
\text { in linewith target } \\
\text { company }\end{array}$ & 0.560 & & \\
\hline & Jobs that challenge & 0.562 & & \\
\hline \multirow{2}{*}{$\begin{array}{l}\text { Work } \\
\text { Engagement }\end{array}$} & $\begin{array}{l}\text { Identification } \\
\text { psychologically on } \\
\text { work }\end{array}$ & & \multirow[t]{2}{*}{0,876} & \multirow[t]{2}{*}{0,934} \\
\hline & $\begin{array}{l}\text { Work result } \\
\text { influence pride }\end{array}$ & & & \\
\hline
\end{tabular}

The next testing stage is discriminant validity. Discriminant validity can be tested by comparing the value of the square root of the AVE with the correlation value between constructs. The square root value of AVE $(0.889 ; 0.887 ; 0.936)$ is greater than the correlation of each construct. To ensure that there are no engraving-related problems, the final step in evaluating the outer model is to test the unidimensionality of the model. The unidimensionality test was carried out by looking at the composite reliability value where the results of the analysis showed the Psychological Climate Composite Reliability value of 0.915 Work Involvement 0.934
Employee perceptions of organizational change 0.815 . All variables have a composite reliability value greater than 0.70 , meaning that all variables are reliable and there is no unidimensionality problem in the model formed.

Table 2. Hypothesis Test Results

\begin{tabular}{|c|l|c|c|c|}
\hline $\mathrm{H}$ & \multicolumn{1}{|c|}{ Variable } & $\begin{array}{c}\text { Coefficient } \\
\text { value }\end{array}$ & $\begin{array}{c}\mathrm{P} \\
\text { values }\end{array}$ & Information \\
\hline 1 & $\begin{array}{l}\text { Perception of } \\
\text { organizational change } \\
-\quad 0,243 \\
\text { climate Psychological }\end{array}$ & 0,000 & Significant \\
\hline 2 & $\begin{array}{l}\text { Perception of } \\
\text { organizational change } \\
- \text { Work engagement }\end{array}$ & 0,036 & 0,104 & $\begin{array}{c}\text { No } \\
\text { Significant }\end{array}$ \\
\hline 3 & $\begin{array}{l}\text { Psychological climate } \\
- \text { Work engagement }\end{array}$ & 0,110 & 0,008 & Significant \\
\hline 4 & $\begin{array}{l}\text { Work engagement - } \\
\text { Psychological climate }\end{array}$ & 0,225 & 0,000 & Significant \\
\hline
\end{tabular}

Based on Table 2 above, it can be seen that the influence of employees' perceptions of organizational change on the psychological climate of the $p$ value < 0.05 . This proves that the first hypothesis, namely the influence of employees' perceptions of organizational change on the psychological climate, is accepted and is proven to have a unidirectional and significant relationship. The test results which have a positive and significant direction of relationship prove the influence of employee perceptions of organizational change on the psychological climate of regionally owned enterprises in Banjarmasin City. These results are because employees accept that changes in the organization will be supported by a psychological climate environment that will improve for employees. Employees' perceptions of changes in the organization and the environment in which they work (psychological climate) have a positive effect and usually tend to judge favorably on these changes. The results of this study are in line with the research of [7], [13], [20].

The second hypothesis is that there is an influence between employee perceptions of organizational change on job involvement, the hypothesis is not accepted because the $\mathrm{p}$ value $>0.05$. This means that employees' perceptions of organizational change during the process of organizational change have no significant effect. This is because employees accept organizational changes that occur and employees feel worried or anxious that they cannot work as expected on these changes. The results of this study are in accordance with the results of research by [18] which states that the impact of failed organizational change will cause employee stress. but does not support the research results of [8], [15], [17]. 
The influence of psychological climate on work involvement has a $\mathrm{p}$ value of $<0.05$. This proves that the third hypothesis, namely the influence of psychological climate on job involvement, is accepted and has a unidirectional and significant relationship. The test results that show the results of the direction of the relationship are positive and significant, explaining that the psychological environment or psychological climate felt by each individual has an influence on employee activities in carrying out work and affects the intensity of the work involved in doing the work more or less. The results of this study are in line with those of [2], [7], [12].

Based on table 2, it can be seen that the effect of work involvement on the psychological climate is $p$ $<0.05$. This proves that the fourth hypothesis, namely the influence of work involvement on the psychological climate, is accepted and has a unidirectional and significant relationship. The test results which have a positive and significant direction of relationship prove the influence of work involvement on the psychological climate of employees of regionally owned enterprises in Banjarmasin City. These results are due to the involvement of employees will express themselves both physically, cognitively and emotionally as well as in other psychological conditions such as job satisfaction. Employees who are involved in their work will be motivated to use the resources they have for their work. The results of this study are in line with the research of [8], [12], [15].

Based on the results of research showing a reciprocal relationship between psychological climate and work involvement, it is proven that the conditions of the environment, especially the psychological climate, can affect work engagement. A good psychological climate in an organization will have an impact on the state of employees while working for employees, for example if the management provides support for their employees, the employees will feel happy and safe in carrying out their work without feeling free to express themselves at work without any limitations. From management, employees feel given recognition by the leadership for the work that has been done. And employee contributions to the company. These things will have a positive impact on employees. The results of this study support the opinion of [2] that a good psychological climate will bring behavioral and attitudinal responses to organizational members. Then the work involvement shown by the employee is . have a great opportunity in his work will be in favor of the type of work and care about the work. So that it will encourage high work involvement among employees which means that it will contribute to the organization according to its goals, and will get support from the leadership to produce work performance and will get recognition from the leadership for these results. The results of this study are in line with the opinion of [8]. Based on the results of data analysis, the indirect effect test shows that the role of psychological climate is important and supports the relationship between employee perceptions of organizational change and job involvement. Because the psychological climate will have an influence in shaping employee perceptions of organizational change. A good psychological climate will affect good perceptions so as to increase high work involvement in the organization. These results are in accordance with research results [7], [9]-[11], [14], [16], [18], [19].

\section{CONCLUSION}

The results of this study indicate that employee perceptions of organizational change have a significant effect on psychological climate but employee perceptions of organizational change have no significant effect on job involvement. Based on the results of research that shows a reciprocal relationship between psychological climate and work involvement. These results show the importance of the role of psychological climate for companies to adapt to changes so that they become better. In order to increase work involvement for employees, organizations or companies need to pay attention to their environment such as a good psychological climate, namely providing support, their role, freedom to express themselves, giving recognition for their work and contribution to the organization [2]. Furthermore, employees must also have a good and positive perception in dealing with organizational change so that it can create a good psychological climate for all parties so that it will increase high work involvement according to the goals of the organization [8], [15], [16].

\section{REFERENCES}

[1] T. J. Doherty and S. Clayton, "The Psychological Impacts of Global Climate Change," Am. Psychol., vol. 66, no. 4, pp. 265-276, 2011, doi: 10.1037/a0023141.

[2] S. P. Brown and T. W. Leigh, "A New Look at Psychological Climate and Its Relationship to Job Involvement, Effort, and Performance," Am. Sociol. Rev., vol. 81, no. 4, 1996, doi: $10.2307 / 2092060$. 
[3] R. Rahmawati, I. Fadah, and A. Juniar, "Psychological Climate Development Strategy At Achmad Yani University Banjarmasin In The Era Of Industrial Revolution 4.0," Int. J. Sci. Eng. Dev. Res., vol. 3, no. 10, pp. 170-174, 2018.

[4] M. G. Ehrhart, B. Schneider, and W. H. Macey, Organizational Climate and Culture. New York: Routledge, 2013.

[5] L. R. James et al., "Organizational and psychological climate: A review of theory and research," Eur. J. Work Organ. Psychol., vol. 17, no. $1, \quad$ pp. 5-32, 2008, doi: $10.1080 / 13594320701662550$.

[6] G. Jacobs, A. Van Witteloostuijn, and J. ChristeZeyse, "A theoretical framework of organizational change," J. Organ. Chang. Manag., vol. 26, no. 5, pp. 772-792, 2013, doi: 10.1108/JOCM-09-2012-0137.

[7] C. P. Parker et al., "Relationships between psychological climate perceptions and work outcomes: A meta-analytic review," J. Organ. Behav., vol. 24, no. 4, pp. 389-416, 2003, doi: 10.1002/job.198.

[8] W. A. Kahn, "Psychological Conditions of Personal Engagement and Disengagement at Work," Acad. Manag. J., vol. 33, no. 4, 1990, doi: 10.1021/la051212i.

[9] S. A. Munyaka, A. B. Boshoff, J. Pietersen, and R. Snelgar, "The relationships between authentic leadership, psychological capital, psychological climate, team commitment and intention to quit," SA J. Ind. Psychol., vol. 43, no. 1, pp. 1-11, 2017, doi: 10.4102/sajip.v43i0.1430.

[10] B. Schneider, V. González-Romá, C. Ostroff, and M. A. West, "Organizational climate and culture: Reflections on the history of the constructs in the journal of applied psychology," J. Appl. Psychol., vol. 102, no. 3, pp. 468-482, 2017, doi: 10.1037/ap10000090.

[11] R. S. Uraon and R. P. Raya, "Psychological climate: Issues and challenges in conceptualization and research," ZENITH Int. J. Bus. Econ. Manag. Res., vol. 7, no. 11, pp. 204217, 2017.

[12] B. N. Vuong, N. N. D. Phuong, and H. Tushar, "The Effects of Psychological Climate Factors on Job Performance in Joint-Stock Commercial Banks in Vietnam," J. Asian Financ. Econ. Bus., vol. 8, no. 4, pp. 1021-1032, 2021, doi: 10.13106/jafeb.2021.vol8.no4.1021.

[13] I. G. P. Kawiana, L. K. C. Dewi, P. S. Hartati, M. Setini, and D. Asih, "Effects of Leadership and Psychological Climate on Organizational Commitment in the Digitization Era," J. Asian Financ. Econ. Bus., vol. 8, no. 1, pp. 1051-1062, 2021, doi: 10.13106/jafeb.2021.vol8.no1.1051.

[14] A. Suratman, S. Suhartini, M. Palupi, F. N. Dihan, and M. B. Muhlison, "The Impact of Psychological Climate and Self-Resilience on Employee Performance During the COVID-19 Pandemic: An Empirical Study in Indonesia," $J$. Asian Financ. Econ. Bus., vol. 8, no. 5, 2021, doi: 10.1080/12294659.2017.1368003.

[15] M. S. Christian, A. S. Garza, and J. E. Slaughter, "Work engagement: A quantitative review and test of its relations with task and contextual performance," Pers. Psychol., vol. 64, no. 1, pp. 89-136, 2011, doi: 10.1111/j.17446570.2010.01203.x.

[16] A. Decuypere and W. Schaufeli, "Leadership and work engagement: Exploring explanatory mechanisms," Ger. J. Hum. Resour. Manag., vol. 34, no. 1, pp. 69-95, 2020, doi: $10.1177 / 2397002219892197$.

[17] A. A. Chughtai, "Impact of Job Involvement on In-Role Job Performance and Organizational Citizenship Behaviour," Inst. Behav. Appl. Manag., 2008.

[18] M. Vakola and I. Nikolaou, "Attitudes towards organizational change: What is the role of employees' stress and commitment?," Empl. Relations, vol. 27, no. 2, pp. 160-174, 2005, doi: $10.1108 / 01425450510572685$.

[19] A. Mulugeta and E. Hailemariam, “Employees' perception towards leadership style and organizational commitment in public organizations," Int. J. Sci. Res. Publ., vol. 8, no. 6, 2018, doi: 10.29322/ijsrp.8.6.2018.p7845.

[20] A. J. Martin, E. S. Jones, and V. J. Callan, "The role of psychological climate in facilitating employee adjustment during organizational change," Eur. J. Work Organ. Psychol., vol. 14, no. 3, pp. 263-289, 2005, doi: $10.1080 / 13594320500141228$. 